\title{
Legal protection of users of financial services in Bosnia and Herzegovina
}

\section{Pravna zaštita korisnika finansijskih usluga u Bosni i Hercegovini}

\author{
Nikolina Vojinovića* \\ ${ }^{a} \mathrm{PhD}$ student, University of Kragujevac, Faculty of Law, Serbia
}

\begin{abstract}
In recent years, the financial market of Bosnia and Herzegovina has been characterized by the expansion of financial services, especially retail lending services, which are offered by various methods and channels of advertising, and in most cases do not comply with regulations governing this area. This paper analyzes the financial market of Bosnia and Herzegovina, with special reference to legal regulations that should be in the function of protecting users of financial services. The financial market is innovative, it has a significant range of financial services, which brings numerous advantages and benefits, but at the same time carries hidden risks for users who, in the long run, become dependent and unprotected from the influence of financial institutions. The aim of this paper is to point out the most common problems faced by users of financial services in Bosnia and Herzegovina and the instruments of legal protection, because there is a huge gap between the declared conditions of use of financial services and realistically achievable rights of users in practice. Today, there are legal solutions regulating relations in the financial sector, but they have been adopted with a delay, thus there is a violation of the basic rights of users of financial services, and monopolistic, we can even say legally unfounded behavior of financial institutions, based on their power and inconsistency in the implementation of legal norms in practice and by authorized state institutions.
\end{abstract}

Keywords: financial services, banks, consumer credit, legal regulations, user rights.

Sažetak: Finasijsko tržište Bosne i Hercegovine karakteriše poslednjih godina ekspanzija finasijskih usluga, posebno usluga kreditiranja stanovništva, koje se nude različitim metodama i kanalima oglašavanja, a u većini slučajeva nisu u skladu sa propisima kojima se uređuje ova oblast. U ovom radu analizira se finasijsko tržište BiH, sa posebnim osvrtom na pravnu regulativu koja treba da je u funkciji zaštite korisnika finasijskih usluga. Finansijsko tržište je inovantivno, raspolaže sa značajnim asortimanom finasijskih usluga, koje donosi brojne

${ }^{*}$ Corresponding author

E-mail address: nikolvojin@gmail.com

This is an open access paper under the license (c) (1) (8) 
prednosti $i$ koristi, ali istovremeno nosi i prikrivene rizike za korisnike, koji dugoročno posmatrano postaju ovisni i nezaštićeni od uticaja finasijskih institucija. Cilj rada je da ukaže na osnovne problem sa kojima se susreću korisnici finasijskih usluga u BiH i na instrumente pravne zaštite, jer postoji ogroman jaz između deklarisanih uslova korištenja finasijskih usluga $i$ realno ostvarivih prava korisnika u praksi. Zakonska rješenja kojima se uređuju odnosi u finasijskom sektoru danas postoje, ali su donesena sa zakašnjem, pa je došlo do narušavanja osnovnih prava korisnika finansijskih usluga i monopolskog, pa možemo kazati i pravno neutemeljenog ponašanja finasijskih istitucija, zasnovanog na njihovoj moći $i$ nedosljednosti sprovođenja pravnih normi u praksi i od strane ovlaštenih, državnih ionstitucija.

Ključne reči: finansijske usluge, banke, potrošački kredit, pravna regulativa, prava korisnika.

\section{Introduction}

The development of the financial sector in Bosnia and Herzegovina intensified in the late 1990s, which enabled citizens and businesses entities access to financial services after many years of non-functioning of all social activities. Banking services are the services used most and most often, and there are also services of insurance companies, microcredit organizations, stock exchanges, leasing companies, investment funds, electronic card issuing companies and the like. The expansion of the use of financial services, especially borrowings from banks, leasing companies and microcredit organizations, has quickly led to excessive, unfounded indebtedness of individuals, households and businesses. In addition to the economic and financial justification for indebtedness of users of financial services in $\mathrm{BiH}$, the question of introducing legal norms in this area is rightly raised in order to legally regulate this economic activity and define the rights and obligations of financial service providers and users. The financial sector and legislation in $\mathrm{BiH}$ were burdened by four years of war, the lack of legal regulations in reference to new social constitution, and the emergence of financial institutions from developed European countries. In such economic and social relations, the needs of the population and the economy for financial resources should have been met as soon as possible which would enable the start and development of production, and raise the standard of living to a higher level. At the same time, there was a need for governing and legal regulation of the financial market. In this paper, we will analyze the financial sector in $\mathrm{B} \& \mathrm{H}$ in the period from 2000 , which is considered the beginning of development, until 2021, with specific reference to legal regulations that protect the rights of users of financial services. The most vulnerable category is loan users.

It is true that this is a short period to analyze such a complex area as it is the financial sector, but in this region the intensity of its development was at a high level, with the participation of domestic and international bodies. Legislation followed its development, sometimes with a delay, and sometimes in a timely manner passing laws and other rules of conduct to regulate the area of finance in $\mathrm{B} \& \mathrm{H}$. The aim of this paper is to find out whether there is legal protection of users of financial services, and to determine its effects and implications on the financial market of $\mathrm{B} \& \mathrm{H}$. In a social community, economic progress occupies a primary place as the basis of all aspects of social life, but in no case should it be left to uncontrolled changes, anarchy or the will of individuals, so a regulatory and control function of state entities in all spheres of economy, including the area of finance, is necessary. Indebtedness of individuals and business entities is in the function of economic development, but increased access to 
loans can lead to taking risks of such a level which, in the disturbed and underdeveloped economy of $\mathrm{B} \& \mathrm{H}$ and uncertainty of political movements, can jeopardize their financial stability and bring them into a dependent position towards creditors. At the same time, there is another problem, and that is the appearance of bad/non-performing placements/loans which disrupts the liquidity of financial institutions and endangers the financial market making a further borrowing process and economic development impossible. The active role of regulatory bodies in this area is necessary in order to establish and maintain business relations based on legal and ethical norms, and the users of financial services deserve special attention.

\section{Financial system of Bosnia and Herzegovina}

The financial system of a socio-economic community is part of the economic system which links different subjects of economic life. It is a complete, complex system of relations between providers and users of financial services and processes, collection, savings, allocation, transformation, transactions and distribution of capital, the function of which some theorists equate with the function of blood flow in the human body. The main tasks and goals of the financial system are to enable the mobility of financial assets, money and money surrogates in financial markets, while respecting all regulatory measures and efficient control. "It consists of several elements financial markets, financial institutions (banks, insurance companies, pension funds, investment companies), financial instruments (bonds, shares, derivatives, etc.), service companies (consulting, information, rating). In recent times, it has been increasingly considering the globalization of financial systems since the financial systems of different countries and regions are connected through information and telecommunication technology" (Aćimović, 2010). The financial system involves several subsystems, banking, monetary, fiscal, showing the complex structure of the financial system, as an integral part of the political and economic system of a country. The financial system is "the cradle of markets, institutions, laws, regulations and techniques through which bonds, stocks and other securities are traded, interest rates are determined, and financial services and products are delivered around the world" (Rose, 2003).

The basic characteristics of the financial system are dynamism, process complexity and openness. Dynamics means that changes which can disturb the balance of relations, legal and ethical norms and jeopardize the control system are constantly taking place in the sector of the financial system of a country or region. Considering the financial system of $\mathrm{B} \& \mathrm{H}$ in the last twenty years, which is, we must admit, a short period of time, we cannot but point out that the structure of this subsystem of the economy has undergone significant changes in terms of quantitative and qualitative indicators, both economically and legally.

The complexity of the process is conditioned by the type of financial market participants, their goals and interests, the attractiveness of money and its surrogates as commodities, and the organization of the social community and political changes. It should not be neglected the role of the state which is, through its bodies, a direct, active participant, but also a regulator of relations on the financial market (Centralna banka Bosne i Hercegovine, 2021b). The nature of financial sector, the possibilities of money 
transfers, modern IT technology, movement and enlargement of capital, trade, financial and other international agreements have made foreign capital predominate in the financial market of $\mathrm{B} \& \mathrm{H}$. The entry of foreign financial institutions into this market has brought new rules of functioning, especially in terms of competitive relations. At the same time, legal solutions related to finance had to be created and implemented. An efficient and effective financial system of $\mathrm{B} \& \mathrm{H}$ should enable the functioning and development of the economic system, and at the same time the overall social prosperity.

The basic elements of the financial system, including the BiH system, are the market, financial instruments and participants or entities in financial markets. The financial market can be viewed in a domain of general definitions of market, so it is a "public place where products and services are bought and sold, directly or through intermediaries" (Samuels et al. 1991). Also, "markets are divided into the market of labor, capital, money, products and services, and production factors" (BahtijarevićŠiber \& Sikavica, 2001). "The market must be regulated from a legal and social standpoint" (Milanović, 1991) It represents a sphere of interest of all factors of social life, so often the financial system is declared as "finance", and a usual synonym for the object of trading in these markets for all values is "money or capital". Above all, it should be emphasized the attractiveness of "money as a commodity". Money is a measure of the value of goods and services in transactional relations and exchange of values in markets. At the same time, it represents a calculated value, a means of exchange and a value preserving means. We can declare the market as a basic element of any financial system because it is not just a place of events, whether real or virtual, but a functional role, where the economic, legal and social interests of individuals and society as a whole are opposed. The financial market is a place where financial instruments are traded and where supply and demand for financial instruments meet. The financial market is part of the financial system. It includes a range of financial institutions and instruments that mediate between participants with a financial surplus and those with a financial deficit (i.e. those in need of funding). The financial market consists of capital markets and money markets" (Centralna banka Bosne i Hercegovine, 2021b).

Financial instruments are objects or, simply stated, tools of trading/exchange in financial markets. Their diversity or development represents the development of financial systems of individual countries and the totality of social relations in socioeconomic terms. In addition to money, there are securities, receivables, deposits and financial rights. "Financial instruments, constituting the collateral, shall mean securities, money market instruments and other financial instruments within the meaning of the law governing the capital market" (Zakon o finansijskom obezbeđenju, 2018). It is interesting to note that the Law on Financial Operations in the Federation of Bosnia and Herzegovina does not mention financial instruments, but states that "financial operations include the acquisition of financial assets, management of financial assets, and allocation of financial assets in order to ensure conditions for conducting the economic activity" (Zakon o finansijskom poslovanju, 2016). According to the Capital Market Act of the Republic of Croatia, "Financial instruments are: transferable securities, money-market instruments, units in collective investment undertakings and derivatives" (Zakon o tržištu kapitala Republike 
Hrvatske, 2021). In the Law on Financial Operations of the Republic of Srpska, financial operations in terms of this law consists of: business financing and payment and maintenance of solvency. Participants or business entities in the financial market are all natural or legal persons that may directly or indirectly participate in transactions in the financial market. Practically speaking, they are natural persons, organized entities in economic, non-economic, cultural, sports, political, religious, public, forprofit, non-profit and other forms of organizing citizens. It should be noted, for economic and legal reasons, that in all financial markets in the world, including $\mathrm{B} \& \mathrm{H}$, there are international entities which, even though they should adhere to domicile laws, impose their own "rules of conduct" which are often based on the arguments of their strength. Conceptual definition, grouping and classification of participants in the financial system of a country is a difficult task for economics and law. Confrontation of different subjects, with a wide range of interest spheres which affect economic development, position of individuals and institutions in society, can jeopardize certain rights concerning personal and economic freedoms, so it is inevitable to regulate the $\mathrm{B} \& \mathrm{H}$ financial market by legal norms. Financial institutions of $\mathrm{B} \& \mathrm{H}$ are the Central Bank of $\mathrm{B} \& \mathrm{H}$, commercial banks, leasing companies, insurance companies, investment-development banks, pension funds, brokerage houses, stock exchanges, microcredit organizations, etc.

"Capital markets in B\&H are regulated at the entity level (FB\&H and RS)" (Centralna banka Bosne i Hercegovine, 2021b). There are numerous problems when it is necessary to classify and group the financial subjects of the financial system of a country, and, in $\mathrm{B} \& \mathrm{H}$, this issue is complicated by the state structure. The most important institution is certainly the Central Bank of $\mathrm{B} \& \mathrm{H}$, which started its operations in August 1997. According to the Constitution of B\&H, "the Central Bank of $\mathrm{B} \& \mathrm{H}$ is the sole authority for issuing currency and for monetary policy throughout Bosnia and Herzegovina" (Ustav Bosne i Hercegovine, 2009).

The paper will be focused on the legislation for regulating the financial market and protecting the users of financial services of commercial banks, as the most important and largest sector of the financial market in $\mathrm{B} \& \mathrm{H}$. There are twenty-three Banks operating in this market. The establishment, business activities, governance, supervision, restructuring and termination of banks in the Republic of Srpska, as well as protection of users of banking services, are defined by the Law on Banks of the Republic of Srpska (Zakon o bankama Republike Srpske, 2016). The Law on Banks of the Federation of Bosnia and Herzegovina regulates the establishment, business operation, governance, supervision of business activities, bank restructuring and termination of banks (Zakon o Bankama Federacije Bosne i Hercegovine, 2017). We have two laws that treat one area, but they have neither formally nor substantially significant differences in legal norms.

The role of banks in business and social life is extremely important in economic and legal terms. On one side, we have needs for financial services, and on the other, the financial market as a "place where supply and demand of financial assets meet" (Orsag, 2011). Activities and organizational structure of banks are determined by the geopolitical principle of organizing communities while, at the same time, their users have no territorial or administrative restrictions in a process of using banking services, 
which is good for a smooth flow of capital, i.e. supply and demand, but requires coordination in implementing legal regulations and control of relations on the market.

\section{Users of financial services and the development of the financial market in B\&H}

The emergence and development of the $\mathrm{B} \& \mathrm{H}$ financial market is inevitably linked to socio-economic relations and events in this region from 1997 onwards. In this relatively short period of time, the financial sector has undergone significant changes in economic and legal terms. The most significant change in the financial market is a reform of the domestic payment system, when the single payment system of B\&H was established. Payment transactions from the Payment Transfer Bureau of the Federation of $\mathrm{B} \& \mathrm{H}$ and the Social Accounting Service have been taken over by commercial Banks. Different terminological definition of institutions that had the same function is a consequence of the use of different languages in B\&H. By innovating legal regulations, there have been changes in a range of services in the banking sector, and thus changes in the portfolio of users of these services. By imposing such legal solutions, the activities of business entities, institutions and citizens had to take place within the banking sector. Although it was declared as a system that "provided a cheap, secure and fast service to participants in domestic payment operations", abandoning the single payment system in B\&H was a step backwards. In practice, banks by such a solution come to a dominant, we can say, superior position in relation to the users of their services. Until then, "banks performed the function of financial intermediation, i.e.: (1) mobilization and concentration of funds, (2) lending operations and (3) commission banking" (Kujavić, 1988). By intensifying the input of foreign capital in the B\&H financial market since 2006, the business focus of the banking sector has been directed at lending, and statistical analyzes show that the loan users are mostly citizens. According to reports on total indebtedness by loan users in B\&H, observed in the period from 1999 to 2021, the share of indebtedness of citizens in the total indebtedness of all users ranged from 3.8 to $47.7 \%$. The poor economic situation, which has caused the low payment standard of $\mathrm{B} \& \mathrm{H}$ citizens on the one hand, and the aggressive marketing campaign of the banking sector on the other have led to excessive, unfounded indebtedness of citizens. "For the analysis, it is important that a part of banking services do not belong to a group of services that customers really want. They are often a "necessary evil" - a means of obtaining products and services for which users do not have enough money" (Babić-Hodović, 2012).

Users of financial services could not nor cannot influence the conditions under which the services are used, such as price, time and manner of use. Users of financial services came to an inferior position in relation to the supply sector, which led to economic dependence reflected in illiquidity. Banks, as a dominant subject of the financial market, receive "bad" loan placements, so a vicious circle begins, when users borrow to repay debts, and banks increase a rate of unpaid receivables, which leaves farreaching consequences. "Banks with majority foreign ownership have often pursued a policy of aggressive lending to the private sector and stimulated demand growth despite significantly higher interest rates compared to the euro area" (Petrović, 2015). 
Not only are retail interest rates significantly higher compared to the surrounding region, but also compared to the loans placed to economic and non-economic organizations. It is justified to ask what the Legislator is doing. An additional problem is the indebtedness of citizens, who due to poor creditworthiness did not have access to favorable bank loans, but did at microcredit organizations with more liberal conditions, and much higher costs. The question is whether the market should have been left to an uncontrolled situation, anarchy, unfair competition or its rules of functioning should be defined by legal norms. Further in the paper, we will analyze legal solutions that protect users of financial services in terms of access to loans, information, financial literacy, contractual relations, loan use and repayment, and dispute resolution.

\section{Legal regulations on the $B \& H$ financial market}

Users of financial services, clients in the financial market, meet their profit or nonprofit-oriented needs, while service providers or creditors achieve their business goals. "A client is any person who uses or has used the services of a bank or a person who has approached a bank in order to use its services, and who has been identified by the bank as such" (Zakon o Bankama Federacije Bosne i Hercegovine, 2017). Legal regulations had two directions. One is when Laws, such as the Law on Protection of Users of Financial Services of the FB\&H, the Law on Leasing of the Republic of Srpska, the Law on Deposit Insurance in Banks of Bosnia and Herzegovina, the Law on Bills of Exchange and the Law on Microcredit Organizations, directly address the rights and protection of users of financial services. The other is when Laws, such as the Law on Domestic Payment Transactions, the Law on the Banking Agency of the Republic of Srpska, the Law on the Banking Agency of the Federation of Bosnia and Herzegovina, the Law on Banks (Republic of Srpska and the Federation of Bosnia and Herzegovina), the Law on Savings and Credit Cooperatives, the Law on Obligations, the Law on Consumer Protection in Bosnia and Herzegovina and the Law on Prevention of Money Laundering and Financing of Terrorism, regulate economic and legal relations in the financial market of Bosnia and Herzegovina. Laws at the level of $\mathrm{B} \& \mathrm{H}$ and Laws at the level of entities are stated here, and this is because "Bosnia and Herzegovina consist of two entities: the Federation of Bosnia and Herzegovina and the Republika Srpska (hereinafter "Entities"). There is freedom of movement throughout Bosnia and Herzegovina. Bosnia and Herzegovina and the Entities shall not impede the full freedom of movement of persons, goods, services and capital throughout Bosnia and Herzegovina" (Ustav Bosne i Hercegovine, 2009). However, in practice, the structural organization of Bosnia and Herzegovina has conditioned those legal relations in this area are regulated at the level of $\mathrm{B} \& \mathrm{H}$ and both at the entity level, so we have the case that when exposing loan offers, banks show different levels of effective interest rate for the Republic of Srpska and the Federation of Bosnia and Herzegovina. Banks' activities are limited in territorial and organizational terms, while the users of their services have the freedom of access and choice of the Bank and services, regardless of the entity administrative boundaries.

The next issue is the timeliness of the adoption and implementation of legal solutions that define legal relations in the financial market of Bosnia and Herzegovina. The enormous indebtedness of the citizens of B\&H started in 2005, and at the end of 2020 
it reached the amount of BAM 11.18 billion. It is right to raise the question about the optimality of borrowing and the possibility of repayment of loans, which can disrupt the functioning of the financial system of $\mathrm{B} \& \mathrm{H}$ in the long run. It is true that legal regulations were delayed, but the area was regulated under the influence of illiquidity of service users, bad loans and the influence of the international community. Lending to citizens, i.e. the use of the services of financial institutions can be divided into three stages. The first stage is informing about the possibilities and conditions to access to credit services and use them. In the second stage, obligatory relations are created between creditors and debtors, and the third stage includes the period of realization of obligatory relations.

\section{Informing users of financial services}

The information on the basis of which users of financial services make decisions have two directions. One is when financial institutions in search of clients expose information by promotional activities towards consumers, and the other is when users search for information. For promotional activities, there are legal norms that determine the rules of conduct, while the search for information is liberalized. Sources from which users can obtain information about financial services are economic advertising of financial institutions, information of institutions that are in the function of financial market control and individuals and associations of users of financial services.

\subsection{Commercial informing}

Providing information about an assortment of financial services, conditions under which they can be obtained and their impact on users is of great importance. First of all, regarding lending, it has its effect in terms of economic and legal aspect over a long period of time, with extremely uncertain events in the region. Advertising by financial institutions is motivated by their achievement of business results, while a search for information by clients is conditioned not only by economic but also by socio-psychological reasons. In order to make an adequate decision, users of financial services need to be well informed and have a minimum of financial literacy. "Advertising is any representation, in any form, given in a framework of a business or independent activity and which is aimed at promotion with a view to promoting the sale of goods or services, including real estate, rights and obligations. Prohibited advertising is misleading advertising and prohibited comparative advertising" (Zakon o nedopuštenom oglašavanju, 2016). Creditors in the financial market of $\mathrm{B} \& \mathrm{H}$, characterized by developed competitive relations, are fighting for the "favor" of clients. Market competition often contained elements of unfair competition, false and "blurred" promises, so users consumed services that were not in line with their capabilities, which had far-reaching, negative consequences for them and the banking sector.

Legal solutions have been enacted and implemented to limit these deviations. Theoretically and practically, regulations and their implementation should be harmonized with the policy and goals of financial sector development, international regulations and standards, communication opportunities, and certainly, the level of financial literacy of borrowers. The scope of loan assortment is arranged by breadth 
and depth. "The conditions of using financial services must be advertised in a clear and understandable manner, and inaccurate and untrue information, or information that could mislead the average user, may not be used when advertising, nor may information that could give a false impression regarding the conditions of using the service and lead the user to make a decision they would not have made under different circumstances be used, nor may data that is harmful or is likely to be harmful to some other services provider be used" (Zakon o zaštiti korisnika finansijskih usluga, 2014). In accordance with the Law on Consumer Protection of the Republic of Srpska, "the rights to be informed is obtaining correct information required for a conscious choice among the offered goods and services" (Zakon o zaštiti potrošača u Republici Srpskoj, 2012). In practice, Banks, through its promotional activities, publish exact data since "it is forbidden for a bank to use inaccurate and untrue information in advertising, as well as data and information which may mislead the average user or can create a misconception about the terms of service and lead the user to making a decision which the user would not make under different circumstances" (Zakon o bankama Republike Srpske, 2016). However, the appeals in propaganda messages contain "tempting" promises and encourage the consumption of financial services, even when there are no minimum, objective conditions for that. Legally observing, banks do not violate legal norms, but their marketing skills and aggressive bidding are certainly not moral nor ethical. Propaganda and psychological impact on consumption in economic conditions in $\mathrm{B} \& \mathrm{H}$ is not limited by legislation, but citizens are left free to assess business risks, but unfortunately this has led to excessive indebtedness of users of loans and other financial services, which threatens the financial system of B\&H. Banks advertise "Quick cash loan. No processing costs for loans up to BAM 50,000, with a repayment period of up to 10 years, approval in just 30 minutes and only with an ID card" (Addiko Bank Banja Luka, 2021). Consumers often make irrational decisions, for the sake of solving existential problems, satisfying their ego, or believing in the marketing tricks of Banks. Directive 2005/29/EC (Direktiva o nepoštenoj poslovnoj praksi, 2005) does not allow "using commercial practice to appreciably impair the consumer's ability to make an informed decision, thereby causing the consumer to take a transactional decision that he would not have taken otherwise" (Direktiva o nepoštenoj poslovnoj praksi, 2005). The Central Bank of $\mathrm{B} \& \mathrm{H}$ reacted to this situation, and its mission is "Raising awareness and educating citizens about the role of the $\mathrm{CBB} \& \mathrm{H}$, and raising the level of knowledge so that all citizens can recognize the benefits of available financial services and use them with understanding in a rational and safe way" (Centralna banka Bosne i Hercegovine, 2021b). There is also the Debt Counseling Manual published in April 2016 (Bahtic ez al., 2016), which was created as a result of cooperation between the CBB\&H and the State Secretariat for Economic Affairs of the Swiss Government, the European Fund for Southeast Europe and the International Finance Corporation, a member of the World Bank Group. A year before, free counseling programs for over-indebted citizens were launched in some B\&H municipalities. However, these were just reactions, which should have happened earlier. In addition to commercial informing, we also have mandatory informing of loan users, which in legal solutions and professional literature refers to consumer protection. When it comes to the conditions and general rules for the use of loans, there are clear legal solutions. The Law on Obligations defines rules on how to create and execute contracts, so this also applies to contracts in the financial sector. "In order to create conditions for free trade of goods 
and services on the market and to meet the material and other needs of citizens, and to ensure the responsibility of companies and other participants in legal transactions to perform their obligations, this law regulates the basis of obligations (general part), contractual and other obligations in the trade of goods and services" (Zakon o obligacionim odnosima Bosne i Hercegovine, 2011). Additionally, "participants in transactions are obliged to act in accordance with a market unity principle and economic policy established, not to disturb market stability and not to harm other market participants, consumers and the community as a whole" (Zakon o obligacionim odnosima Bosne i Hercegovine, 2011). This law provides general provisions on the emergence and development of obligations between providers and users of financial services.

\subsection{Informing loan users in a pre-contractual stage}

Informing about conditions and possible consequences is crucial for loan users. The basic function of lending is to improve the economic position of population. However, the risk taken by this act can be many times greater than the benefits that are achieved, as shown by the practice in B\&H. A novelty in this area was the Law on Protection of Users of Financial Services of the FB\&H adopted in 2011, which was formulated in accordance with the content of Directive 2008/48/EC on consumer credit agreements. Directive 2008/48/EC does not apply to "credit agreements which are secured either by a mortgage or by another comparable security commonly used in a Member State on immovable property or secured by a right related to immovable property and credit agreements involving a total amount of credit less than EUR 200 or more than EUR 75 000" (Direktiva o ugovorima o potrošačkim kreditima, 2008). The same solutions are provided by the FB\&H Law on Protection of Users of Financial Services. It remains unclear why the scope of application of the Directive and the Law has not been expanded when there are consumer credits and indebtedness of citizens (credit cards, current account overdrafts, leasing, consumer credit) which are not included, but take a significant part in total retail indebtedness.

The loan seeker can obtain the first official information when they submit a request for a loan approval, and it is a common practice to follow the opening of a current account, filling out questionnaires and documenting all the information that a bank requests from a client. An inferior position is already being formed there. Until the final analysis of the loan request and the bank's decision to approve/disapprove the loan, the loan seeker is in uncertainty about resolving the request. In practice, the deadline for approval is about thirty days, during which period, they must "supplement their request" at creditor's demand. "During the negotiation phase, the bank shall be obligated to inform the user about the terms and conditions and all essential characteristics of the service offered in the form of a standard information sheet which shall be presented to the user as a representative example of the service, in written or electronic form" (Zakon o bankama Republike Srpske, 2016). The basis of such a legal solution in B\&H is found in Directive 2008/48/EC, which indicates all the standard information that the creditor must provide to the future user. This aims to achieve transparency and selection of the most favorable offer and to eliminate or mitigate financial risk in the future. The information refers to the interest rate (nominal and effective interest rate), loan costs, annuity amount, repayment period, security 
instruments, warnings regarding the consequences of default, the right of the user to withdraw from the contract, repayment of debt or part of debt, etc. Directive 2008/48/EC, Art. 18, states "such information should be given in a clear, concise and prominent way by means of a representative example" which is rare in B\&H practice. Information is presented to consumers on the websites of banks, orally in conversation with employees or representatives and through an "Information Sheet". "An offer is a proposal for the conclusion of a contract made to a certain person, which contains all the essential components of the contract so that by accepting it, the contract could be concluded" (Zakon o obligacionim odnosima Bosne i Hercegovine, 2011). The information sheet is considered as, and actually it is, an offer to conclude a contract, and at the same time should be the "protector" of credit service users. "Before the signing of a contract, the bank shall be obligated to provide the user with all information about the service or make available all essential terms and conditions and elements of the contract from which the rights and obligations of the contracting parties are clearly evident, and at the user's request, free of charge, hand over the contract draft for consideration outside bank premises, within a period defined in the standard information sheet" (Zakon o bankama Republike Srpske, 2016). Bank information sheets contain all the information that a loan seeker should have before signing a loan contract. However, the information sheets contain information that is contrary to legal solutions, insufficient, and there are different conditions for FB\&H, RS and Brčko District:

1. "The early repayment fee may be calculated in relation to the amount of the remaining principal sum of the loan" (Privredna banka Sarajevo, 2019). However, the Law on Protection of Users of Financial Services of FB\&H, Art. 27 states precisely: "(2) In the event of early loan repayment, the bank has the right to a objectively justified and contracted compensation for costs directly related to the early loan repayment; (3) The fee referred to in Paragraph (2) of this Article can be contracted up to the amount of damages incurred due to early repayment and up to a maximum of $1 \%$ of the amount of the prepaid loan" (Zakon o zaštiti korisnika finansijskih usluga, 2014).

2. "The agreed loan may be repaid in part or in full and before the agreed repayment period, with the obligation to notify the Bank in advance in written form, within 8 (eight) days prior to the intended repayment" (Raiffeisen bank, 2018). Further in the text of the information sheet, the partial repayment is not mentioned at all. $\breve{Z}$

3. "For all due unpaid liabilities, written notifications are submitted, the costs of which are borne by the user in the RS and Brčko District if the notification is duly delivered or returned to the bank due to the impossibility of delivery" (Komercijalna banka, 2021).

"Financial services providers cannot charge warning letters for late payment of due liabilities of the user under contracts referred to in this Law, including warning letters with respect to the contracts referred to in Article 3 of this Law, starting from the date of this Law's entry into force" (Zakon o zaštiti korisnika finansijskih usluga, 2014). Note: Information sheets are downloaded from Banks' websites. The question is the amount of information presented to the consumer, and the consumer's ability to accept and understand it. Loan seekers are differentiated in reference to education level, age, type of occupation, cash income, financial literacy, and differences in their 
expectations and perceptions. A higher education level is not a prerequisite for understanding all the provisions of the information sheet. The terminology of concepts and processes, complexity of financial relations and long-term obligations require education of users, so Banks are expected to, in addition to written information, present all possible risks in oral conversation too.

\subsection{Informing in a stage of agreeing on a credit arrangement}

The contractual stage or loan approval follows the analysis and verification of the data contained in the loan request, data from the records of institutions authorized to monitor the indebtedness of individuals and legal entities and all others necessary to assess the creditworthiness of the loan seeker. The conclusion of a loan agreement depends exclusively on the Bank's attitude towards the fulfillment of the prescribed conditions for loan approval, i.e. creditworthiness assessment. The role of the seeker is passive. "To assess the credit status of a consumer, the creditor should also consult relevant databases; the legal and actual circumstances may require that such consultations vary in scope" (Direktiva o ugovorima o potrošačkim kreditima, 2008). The assessment of the creditworthiness of the loan seeker is performed on the basis of the presented official documents, statements, certificates and the results of quantitative analyzes. "Prior to approval of loans and other facilities, the bank shall run the credit standing assessment of the principal debtor, co-debtor and guarantor" (Agencija za bankarstvo Federacije Bosne i Hercegovine, 2014). Credit standing analysis is not only mandatory by regulations, but it is purposeful for both the provider and the loan seeker, in order to minimize side effects. The bank is obliged to manage business risks, and in particular the risk of "loss stemming from a debtor's failure to repay their liabilities to the bank" (Zakon o Bankama Federacije Bosne i Hercegovine, 2017).

Not only is the client's current ability to accept financial liabilities analyzed, but credit history is also important. "Prior to concluding a loan agreement, the bank shall perform an assessment of creditworthiness and credit history of the principal debtor, co-debtor and guarantor based on relevant documentation and information obtained from all participants in a credit relationship, by an insight into data in the Central Credit Registry (CCR) and other loan registers, conditioned by a written consent of a person to whom the register data refer to, as well as other public registers and databases" (Agencija za bankarstvo Federacije Bosne i Hercegovine, 2014). CCR Central Credit Registry of Business Entities and Natural Persons in Bosnia and Herzegovina (hereinafter: Registry) contains the data on credit and other indebtedness of business entities and natural persons of participants in the Registry (Centralna banka Bosne i Hercegovine, 2021b). CCR - The Report on current and settled indebtedness exists as form BF1, BF2, BP1, BP2.

"The decision to approve/disapprove a credit is made exclusively by the creditor, and regardless of how well the user was informed, the user is not the one who makes the decision on the credit" (Fejös, 2009) When approving a loan, "lenders should take into account the borrowers' interests and needs throughout the relationship in order to prevent consumer detriment, but also prevent social, societal and economic detriment, at macro-level, when indebtedness reach high levels" (Responsible consumer credit lending, Financial Services user Group, 2019), This relationship, which is defined by 
economic, legal and ethical norms, prevents unfair business practices. Banks present to clients or should present all the effects and implications that may arise from borrowing, including also changes that may occur independently of the will of the parties. Here we primarily mean the changes of variables, Euribor and Libor, which are the elements on the basis of which the variable interest rate is determined. Mandatory elements of the loan agreement are determined by the Law on Obligations and the Law on Protection of Users of Financial Services in B\&H. The loan and microloan agreement must contain seventeen essential elements (Zakon o zaštiti korisnika finansijskih usluga, 2014). "The contract on the use of a financial service, which is concluded with the user, is to be in written form. Each contracting party receives a copy of the contract" (Zakon o zaštiti korisnika finansijskih usluga, 2014 Zakon o zaštiti korisnika finansijskih usluga, 2014). The essential provisions of the contract are imperative, and the user is not given the possibility to influence the creation and realization of obligatory relations. The protection of the user, as a weaker contracting party, is of a declarative nature and is reflected in the prohibition of changing the obligatory elements of the contract without the user's prior written consent. The creditor may not unilaterally change the terms of the credit arrangement, nor terminate it. When a variable interest rate is agreed, the situation is more complex. "A credit with a variable interest rate is a credit in which the interest rate is not fixed during the term of the credit agreement but may vary" (Centralna banka Bosne i Hercegovine, 2021a). The variable interest rate is calculated depending on the amount of the Bank's margin, as a constant value and the amount of Euribor or Libor, as elements the value of which can change. Changes in the value of currencies (changes in $\mathrm{CHF}$ values) have put credit users in a difficult position. Changes in the value of currency index, as well as changes in the value of Euribor and Libor, occur independently of the will of contracting parties and are known only at the time of the conclusion of the contract. Banks are protected because they have a fixed margin value, while all the burden of negative changes of variables is transferred to the borrower. "If a variable nominal interest rate has been contracted, the bank, microcredit organization, or lessor shall inform the user in written or electronic form of the change in that rate and they shall do so before beginning to apply the changed rate or periodically in accordance with the contract, listing the date on which the changed rate began to be applied in that notice (Zakon o zaštiti korisnika finansijskih usluga, 2014). A practical question that arises is how the Banks calculated the annuity to the users if they did not know, nor could they know, the value of the annuity, and the basis for its determination was the exchange rate of the foreign currency in relation to the domestic one. The next question is why the Banks did not adjust the value of the interest rate in the case of a decrease in the value of Libor or Euribor in relation to the contracted one in accordance with the defined time in the contract. Such attitude of banks was also the subject of litigation.

Banks carried out prescribed procedures in the pre-contractual and contractual phase, but not in the repayment period. It can be said that there was only formal or declarative protection of users of financial services. There was no individual or public disclosure of information when the change of variable values was to their "detriment", but when the change of these values led to an increase in interest rates, this was reflected through an increase in annuities. "Member States should take appropriate measures to promote responsible practices during all phases of the credit relationship, taking into account 
the specific features of their credit market. Those measures may include, for instance, the provision of information to, and the education of consumers, including warnings about the risks attaching to default on payment and to over-indebtedness" (Direktiva o ugovorima o potrošačkim kreditima, 2008). The question is whether it is sufficient to inform users about their rights, obligations and possible sanctions, or it is necessary to point out certain circumstances that may affect their creditworthiness, and which are beyond their influence. This requires expertise, and not just the commercial orientation of banks, in order to really achieve the legally proclaimed protection of financial service users.

\section{Rights of loan users}

The rights of users of financial services are defined by legal solutions. They are mostly considered only in the loan repayment phase i.e. when "problems" appear. In addition to the right to information and the "choice of the best offer", "the user has the right to withdraw from the concluded loan/microloan agreement, financial leasing arrangement, contract on permitted account overdraft, contract on payment card issuance and use within 14 days of signing the contract without giving a reason for the withdrawal" (Zakon o zaštiti korisnika finansijskih usluga, 2014). "The financial service provider cannot make the loan funds available to the user prior to the expiration of a period of 14 days from the date the contract was concluded, except at the explicit request of the user" (Zakon o zaštiti korisnika finansijskih usluga, 2014). However, the legal deadline of 14 days is shortened in such a way that Banks provide customers with the opportunity to waive their right to withdraw from the concluded loan agreement in written form of their own free will. This is explained by the "urgency of the request" of the user.

The next dilemma arises from Art. 26, Item 3 of the Law on Protection of Users of Financial Services in B\&H, which states "that in the case of loan/microloan agreements secured by a mortgage as well as in the case of purchase agreements or real estate purchase agreements, the user can withdraw from the contract provided that they have not started using the loan/microloan or financing" Zakon o zaštiti korisnika finansijskih usluga, 2014). Making funds available to the user by the creditor and the beginning of the use or non-use of funds have different effects and implications. The funds available to the user (set on his account) are in their ownership and then certain rights and obligations arise for the user, and the previous "owner" of the funds has the rights defined by the loan agreement. Any further consideration of this issue concerns only the fulfillment of obligations arising from the debtor-creditor relationship. "A user that withdraws from a loan/microloan agreement, contract on permitted account overdraft and contract on payment card issuance and use shall immediately and within 30 days of sending the notice referred to in Paragraph (4) of this Article return to the bank the principal and the interest from the main operation during the use of the loan/microloan" (Zakon o zaštiti korisnika finansijskih usluga, 2014). The right to withdraw is not conditioned by the payment of "costs" for the user, as in the case of early repayment, but they must pay the corresponding amount of interest during the "use" of funds. The question is whether it is justified to pay interest for "non-use" of funds, which is a condition for giving up the loan. 
The consumer has the right to repay the debt early, in part or in full, within the stipulated/contracted repayment period. "The debtor of the monetary obligation may fulfill it prior to the deadline" (Zakon o obligacionim odnosima Bosne i Hercegovine, 2011). For the Bank, although "it has the right to a objectively justified and contracted compensation for costs directly related to the early loan repayment" (Zakon o zaštiti korisnika finansijskih usluga, 2014). this is nevertheless a reduction in the projected profit. "The user has the right to repay the loan at any given moment, in whole or in part, prior to the repayment deadline, while being entitled to having the total cost of the loan reduced by the amount of interest and the costs for the remainder of the contract (prepayment), but also being required to inform the bank in advance within the contracted period of their intention to prepay the loan" (Zakon o zaštiti korisnika finansijskih usluga, 2014). According to previous legal solutions, the fee for early repayment of the loan in use was equal to the amount of the commission for "processing" the loan. The user of financial resources in terms of exercising their rights and interests "has the right to complaint if they believe that the financial service provider does not comply with the provisions of the law, general business conditions, good business practices and contractual duties" (Zakon o zaštiti korisnika finansijskih usluga, 2014). The competence of RS Banking Agency is also "adoption of acts and undertaking actions in order to ensure the protection of consumer rights" (Zakon o Agenciji za bankarstvo Republike Srpske, 2013). "If the financial service provider does not submit a response within the period specified in Paragraph (2) of this Article or if the complainant is not satisfied with the response, the complainant has the right to notify the Ombudsman of it in written form and file a complaint" (Zakon o zaštiti korisnika finansijskih usluga, 2014). The competencies and powers of the Ombudsman are "to investigate all complaints made about the poor functioning of the judicial system or the poor administration of an individual case and to recommend appropriate individual or general measures" (Zakon o ombudsmenu za ljudska prava Bosne i Hercegovine, 2008). We emphasize that the Ombudsman can only recommend certain measures. The user of credit can also contact the Banking Agency, which was "established to regulate and control the banking system" Zakon o Agenciji za bankarstvo Republike Srpske, 2013). Practice has shown that upon receipt of a complaint, theAgency requests a statement from the financial service provider and submits the received response to the complainant, without going into the analysis of the legality of banks' work, with a recommendation to apply to the competent court to exercise their rights. These solutions provide only the possibility of resolving user complaints, while the final outcome can only be guessed or predicted.

\section{Conclusion}

In a short period of time, the financial sector of Bosnia and Herzegovina has had significant changes in qualitative and quantitative terms. Its role in socio-economic relations, the number of participants, the values that has been achieved in the financial markets, condition the necessity of legal regulation in this area. The biggest changes took place in the field of retail lending. Aggressive economic propaganda of banks, illiquidity and lack of funds, the needs of citizens for economic development after the war, have led to an enormous growth of the credit sector in all its forms in the last two decades. The underdevelopment of the economy, negative economic trends, the lack of legal regulations, the lack of a database on the indebtedness of individuals and legal 
entities have led to the over-indebtedness of users of financial resources. As a result, a large number of bad/non-performing loans appear, which burdens the operations of banks, and users seek a way out in new debts, which makes the already unfavorable liquidity more difficult. The complexity of the constitution of $\mathrm{B} \& \mathrm{H}$ as a state, in political and economic terms, has favored this kind of financial market development. On the one hand, we have a market-commercial orientation of domestic and foreign banks to make as much profit as possible based on lending to citizens and, we can say, financial illiteracy and lack of information of loan users on the other. It is not uncommon for citizens to have to borrow money to make a living. The operations of all entities on the financial market of $\mathrm{B} \& \mathrm{H}$ are defined by the Laws, but their adoption and implementation were not timely. The adopted legal solutions did not deal with the causes that led to over-indebtedness of citizens, but only with the consequences, and in addition to delayed effects, they did not fully address all the problems that arose from the arbitrariness of banks. The users of financial services were, and still are, in an inferior position in relation to financial institutions. Their impact on banks' operations, interest rates, loan approval procedures and the manner and conditions of repayment was minor.

In order to establish a balance in these relations between creditors and debtors in $\mathrm{B} \& \mathrm{H}$, it was adopted the Law on the Protection of Users of Financial Services. The adoption of this law was a belated reaction of the legislator to Directive 2008/48/EC of the European Parliament and of the Council. The Law on Banks of the Republic of Srpska and the Law on Banks of the Federation of Bosnia and Herzegovina regulate the establishment and operation of banks, while the control of the banking sector is performed by the Banking Agencies of the Republic of Srpska and the Federation of $\mathrm{B} \& \mathrm{H}$. Implemented legal norms have undergone significant changes in terms of protection of users of financial services, but not to a sufficient extent. Practice has shown that there is still the arbitrariness of banks, different and selective interpretation and application of legal solutions in practice. It was most evident in the application of the "variable interest rate" and foreign currency indices. The obligatory, debtorcreditor relationship is based on the need to "return what was obtained with a corresponding value". Banks seemingly lower the interest rate as a percentage, while the value of the effective interest rate increases due to the costs of operating an account, insurance premiums, collateral and other fees. The legislator did not envisage any protection of loan users on this issue, but even remained silent on the events regarding the "Swiss", where the main problem was, in addition to the growth of foreign exchange rates, in applying and calculating the variable interest rate according to Libor and Euribor as variables.

It is not sufficient to regulate this area just institutionally, but it is necessary to achieve legal protection of users of financial services through the application and consistent implementation of legal solutions. It is evident that there are difficulties in the financial market of $\mathrm{B} \& \mathrm{H}$ in exercising and protecting the financial rights of citizens. In addition to legal solutions, there are also initiatives to increase financial literacy. The Central Bank of B\&H, the Banking Agency, the Ombudsman and the courts should work together in a synchronized manner to resolve the issue to protect and obtain financial rights. In order for the adopted legal solutions to become a part of the 
business reality, it is necessary to permanently respect and enforce laws, as well as to sanction all forms of their non-compliance in practice.

\section{References}

Addiko Bank Banja Luka. (2021). Addiko Blic gotovinski kredit. https://www.addikors.ba/gradjani/krediti/blic-gotovinski-kredit/

Agencija za bankarstvo Federacije Bosne i Hercegovine. (2014). Odluka o uvjetima za procjenu $i$ dokumentiranje kreditne sposobnosti. https://www.fba.ba/images/banke_podzakonski_2/Banke_Kreditna_sposobnos t_bos.pdf

Aćimović, S. (2010). Ekonomski rečnik. Centar za izdavačku delatnost Ekonomskog fakulteta u Beogradu.

Babić-Hodović, V. (2012). Marketing u bankarstvu. Ekonomski fakultet u Sarajevu.

Bahtijarević-Šiber, F., \& Sikavica, P. (2001). Leksikon menedžmenta. Masmedia.

Centralna banka Bosne i Hercegovine. (2021a). Promenljiva kamatna stopa. http://fined.cbbh.ba/press/edukacija/891

Centralna banka Bosne i Hercegovine. (2021b). Metodološka objašnjenja. https://www.cbbh.ba/content/read/792

Direktiva o nepoštenoj poslovnoj praksi (2005). Službeni List Europske Unije, Direktiva Europskog parlamenta i vijeća br. 2005/29/EZ. http://data.europa.eu/eli/dir/2005/29/oj

Direktiva o ugovorima o potrošačkim kreditima. (2008). Službeni List Europske Unije, Direktiva Europskog parlamenta i vijeća br. 2008/48/EZ. http://data.europa.eu/eli/dir/2008/48/oj

Fejos, A. (2009). The Impact of Information on Responsible Lending and Responsible Borrowing in the European Union. Pravni zivot (Legal Life-Serbian Journal of Legal Studies), 6(12), 751-764.

Komercijalna banka. (2021). Dugoročni krediti. https://www.kombankbl.com/dugorocni-krediti-mikro-biznis

Kujavić, B. (1988). Definicijsko modeliranje društveno-ekonomske uloge banaka. Ekonomski vjesnik: Review of Contemporary Entrepreneurship, Business, and Economic Issues, 1(1), 77-86.

Milanović, R. (1991). Osnovi marketinga. Svjetlost.

Orsag, S. (2011). Vrijednosni papiri: Investicije i instrumenti financiranja. Revicon.

Petrović, A. (2015). Novo pravno uređenje financijskih usluga u bih-koliko su korisnici stvarno zaštićeni? Zbornik radova Pravnog fakulteta u Nišu, 54(70), 801-822.

Raiffeisen bank (2018). Uslovi odobravanja namenskih kredita. raiffeisenbank.ba/sites/default/files/dokumenti/2018-03/Nenamjenski krediti.pdf

Bahtić, A., Begić, H., \& Limo, T. (2016). Priručnik za savjetovanje zaduženih građana Sarajevo. Centralna banka Bosne i Hercegovine

Privredna banka Sarajevo. (2019). Informacioni list - stambeni kredit sa hipotekom. https://www.pbs.ba/wp-content/uploads/2019/09/INFORMACIONI-LISTStambeni-kredit-sa-hipotekom-07_2019.pdf 
Financial Services user Group. (2019). Responsible consumer credit lending - FSUG opinion and recommendations for the review of the Consumer Credit Directive. Financial Services user Group.

Rose P.S. (2003). Money and Capital Markets. $8^{\text {th }}$ edition. McGraw-Hill https://doi.org/10.4324/9780203448960

Samuels, I. M., Wilkes F. M., \& Brayshaw R. E. (1991). Management of Company Finance. $5^{\text {th }}$ edition. Chapman $\&$ Hall.

Ustav Bosne i Hercegovine. (2009). Službeni glasnik Bosne i Hercegovine, br. 25/2009.

Zakon o Agenciji za bankarstvo Republike Srpske. (2013). Službeni glasnik Republike Srpske, br. 59/2013, 4/2017.

Zakon o Bankama Federacije Bosne i Hercegovine. (2017). Službene novine Federacije Bosne i Hercegovine, br. 27/2017.

Zakon o bankama Republike Srpske. (2016). Službeni glasnik Republike Srpske, br. 4/2017, 19/2018, 54/2019.

Zakon o finansijskom obezbeđenju. (2018). Službeni glasnik Republike Srbije, br. $44 / 2018$.

Zakon o finansijskom poslovanju. (2016). Službene novine Federacije Bosne $i$ Hercegovine, br. 48/2016

Zakon o nedopuštenom oglašavanju (2016). Službene novine Federacije Bosne $i$ Hercegovine, br. 101/2016.

Zakon o obligacionim odnosima Bosne i Hercegovine. (2011). Službeni list SFRJ, br. 29/1978, 39/1985, 45/1989 - odluka USJ i 57/1989, Službeni list RBiH, br. 2/1992, 13/1993 i 13/1994 i Službene novine FbiH, br. 29/2003 i 42/2011.

Zakon o ombudsmenu za ljudska prava Bosne i Hercegovine. (2008). Službeni glasnik BiH, br. 19/2002, 35/2004, 32/2006, 38/2006 - ispr. i 50/2008 - dr. zakon

Zakon o tržištu kapitala Republike Hrvatske. (2021). Narodne novine - Službeni list Republike Hrvatske, br. 65/2018, 17/20, 83/2021.

Zakon o zaštiti potrošača u Republici Srpskoj. (2012). Službeni glasnik Republike Srpske, br. 6/2012, 63/2014, 18/2017.

Zakon o zaštiti korisnika finansijskih usluga. (2014). Službene novine Federacije Bosne i Hercegovine, br. 31/2014.

Received: 16 August, 2021; Accepted: 17 September, 2021.

Rad je primljen: 16.08.2021; Prihvaćen: 17.09.2021. 